\title{
Effect of Different Probiotics on Broiler Carcass and Meat Quality
}

Author(s)

Pelicano ERL

Souza PA de

Souza HBA de

Oba A

Norkus EA

Kodawara LM

Lima TMA de

Departamento de Tecnologia

Faculdade de Ciências Agrárias e Veterinárias Unesp

\section{Mail Address}

Elizabete Regina Leone Pelicano

Departamento de Tecnologia

Faculdade de Ciências Agrárias e Veterinárias Unesp

Via de Acesso Prof. Paulo Donato Castellane $s / n^{\circ}$

km 5 - Jaboticabal - SP - Brazil

14.884-900

Telephone: (55) 1632092675 , ext. 245

Fax: $\quad$ (55) 1632092675

E-mail: erlpelicano@yahoo.com.br

\section{Keywords}

Broilers, carcass yield, meat quality, organoleptic characteristics, probiotics.

\section{Acknowledgements}

The authors thank Fundação de Amparo à Pesquisa do Estado de São Paulo (FAPESP) for financial support.

\section{ABSTRACT}

The present work evaluated the effect of different probiotics on carcass and meat quality of broilers. One thousand and fifty male Cobb chicks were distributed at one day of age in a randomized design with $3 \times 2+$ 1 factorial arrangement ( 3 probiotics, 2 levels of probiotics in drinking water and 1 negative control group), using 5 replications with 30 birds. Carcass yield was higher $(p<0.05)$ in control birds. Nevertheless, the groups fed with probiotics showed higher $(p<0.01)$ leg yield at 45 days of age. There was a significant decrease in color (lightness) and increase in $\mathrm{pH}$ of breast muscle 5 hours after slaughter in the probiotics treated birds. In the sensory analysis, meat flavor and general aspect 72 hours after slaughter were better when probiotics were added in both water and diet. There were no differences in water holding capacity, cooking loss and shearing force among different probiotics or between them and the control. Thus, meat quality was better when probiotics were fed in the water and diet instead of only in the diet. Nevertheless, carcass and meat quality showed no alteration when the control group was compared to birds fed with probiotics, except for leg yield improvement in the latter.

\section{INTRODUCTION}

For many years, poultry industry has been looking for improvement of production indexes and broiler growth through breeding changes in detriment of the final quality of products. Many factors may lead to alterations in meat quality. The most directly related to meat quality are pre- and post-slaughter practices, bird age, strain, sex, environment and nutrition, and, within the latter, antibiotics have been particularly considered by international health institutes, such as the Food and Drug Administration (FDA).

There is currently a world trend to reduce the use of antibiotics in animal food due to the contamination of meat products with antibiotic residues (Menten, 2001), as well as the concern that some therapeutic treatments for human diseases might be jeopardized due to the appearance of resistant bacteria (Dale, 1992). Some consumer groups are avoiding meat from birds fed with diets containing antibiotics, specially in some countries that import 12 to $14 \%$ of the Brazilian broiler meat (Tabelas da Avicultura, 1995). Nevertheless, according to the United States Department of Agriculture (USDA), $100 \%$ of the broilers and turkeys, $90 \%$ of the swine and $60 \%$ of the beef cattle produced in the USA are fed antibiotics in the diet as growth promoters during the rearing period. In Brazil, with the exception of naturally grown or "caipira" birds, probably almost all broilers are given growth promoters as additives in ration (Menten, 2002). Recently, alternatives for substituting these traditional growth promoters have been evaluated and probiotics have been the most studied. 
Pelicano ERL, Souza PA de, Souza HBA de, Oba A, Norkus EA, Kodawara LM, Lima TMA de
Effect of Different Probiotics on Broiler Carcass and Meat Quality
Probiotics are microorganisms that are fed to animals to colonize the intestinal environment and promote a better flora balance (Fuller, 1989). Besides, these microorganisms are responsible for production of vitamins of the B complex and digestive enzymes, and for stimulation of intestinal mucosa immunity, increasing protection against toxins produced by pathogenic microorganisms.

The use of probiotics for meat and carcass quality improvement has been questioned and many unclear results have been shown. Some authors reported advantages of probiotic administration (Burkett et al., 1977; Jensen \& Jensen, 1992; Maruta, 1993; Corrêa et al., 2000; Vargas Jr. et al., 2002), whereas others did not observe improvement when probiotics were used (Owings et al., 1990; Quadros et al., 2001). Hence, the aim of this study was to evaluate the use of different probiotics on qualitative traits of broiler carcass (yield) and meat (color, pH, water holding capacity, cooking loss, shearing force and sensory analysis).

\section{MATERIAL AND METHODS}

\section{Experimental design and treatments}

The experiment was conducted at the Poultry Experimental Facilities at Faculdade de Ciências Agrárias e Veterinária (Unesp), in Jaboticabal, São Paulo State, Brazil, from April 17th to May 31'st 2001 . Minimum and maximum temperatures during the experimental period were $12^{\circ} \mathrm{C}$ and $25^{\circ} \mathrm{C}$, respectively. One day-old male chicks from Cobb strain were used. One thousand and fifty birds were vaccinated for Marek's disease and fowl pox at hatchery. Chicks were assigned to 35 pens (2.75 $\mathrm{m} \times 1.4 \mathrm{~m})$ in the experimental poultry house. There were 30 birds per pen for a final density of 8 birds $/ \mathrm{m}^{2}$. Infrared lamps were used to provide initial heating. After the second week of age, initial drinkers and feeders were replaced by automatic drinkers and hanging tube feeders with capacity of $20 \mathrm{~kg}$.

The broilers were distributed in a randomized design with $3 \times 2+1$ factorial arrangement, considering three probiotic sources added to the diet (Bacillus subtilis, Bacillus subtilis and Bacillus licheniformis; and Saccharomyces cerevisiae), two concentrations of probiotic in drinking water (with or without probiotic) and one control group (negative control), with a total of 7 treatments and 5 replications with 30 birds. Three birds were used per replication for analysis of carcass yield and parts yield (105 birds); two birds were used per replication for analysis of color, $\mathrm{pH}$, water holding capacity, cooking loss and shearing force (70 birds) and two birds were used per treatment for sensory evaluation (14 birds).

The treatments were denominated as follows:

$\mathbf{T}_{1}=$ Negative control (no probiotic added);

$\mathbf{T}_{\mathbf{2}}=$ Addition of probiotic to the diet (Bacillus subtilis, $10^{10}$ colony forming units (CFU)/g product) and no probiotic added to the drinking water;

$\mathbf{T}_{3}=$ Addition of probiotic to the diet (Bacillus subtilis, $10^{10} \mathrm{CFU} / \mathrm{g}$ product) and to the drinking water (Lactobacillus reuteri, $6.6 \times 10^{9} \mathrm{CFU} / \mathrm{g}$ product; Lactobacillus johnsonii, $3.3 \times 10^{9} \mathrm{CFU} / \mathrm{g}$ product);

$\mathbf{T}_{\mathbf{4}}=$ Addition of probiotic to the diet (Bacillus subtilis, $1.6 \times 10^{9} \mathrm{CFU} / \mathrm{g}$ product; Bacillus licheniformis, $1.6 \times$ $10^{9} \mathrm{CFU} / \mathrm{g}$ product) and no probiotic added to the drinking water;

$\mathbf{T}_{5}=$ Addition of probiotic to the diet (Bacillus subtilis, $1.6 \times 10^{9} \mathrm{CFU} / \mathrm{g}$ product, Bacillus licheniformis, $1.6 \times$ $10^{9} \mathrm{CFU} / \mathrm{g}$ product) and to the drinking water (Lactobacillus reuteri, $6.6 \times 10^{9} \mathrm{CFU} / \mathrm{g}$ product; Lactobacillus johnsonii, $3.3 \times 10^{9} \mathrm{CFU} / \mathrm{g}$ product);

$\mathbf{T}_{6}=$ Addition of probiotic to the diet (Saccharomyces cerevisiae, $8 \times 10^{9} \mathrm{CFU} / \mathrm{g}$ product) and no probiotic added to the drinking water; and

$\mathbf{T}_{7}=$ Addition of probiotic to the diet (Saccharomyces cerevisiae, $8 \times 10^{9} \mathrm{CFU} / \mathrm{g}$ product) and to the drinking water (Lactobacillus reuteri, $6.6 \times 10^{9} \mathrm{CFU} / \mathrm{g}$ product; Lactobacillus johnsonii, $3.3 \times 10^{9} \mathrm{CFU} / \mathrm{g}$ product).

The commercial products containing the microorganisms were added to diet following manufacturers' instructions:

- Bacillus subtilis - based probiotic was added to the diet in a proportion of $300 \mathrm{~g}$ per ton, throughout the rearing period ( $1-45$ days of age);

- Bacillus subtilis and Bacillus licheniformis - based probiotic was added in a proportion of $1,000 \mathrm{~g}$ per ton of starter diet (1-21 days of age) and $400 \mathrm{~g}$ per ton of diet throughout growing phase until slaughter (22-45 days of age);

- Saccharomyces cerevisiae - based probiotic was added in a proportion of 2,000 g per ton of starter diet (1-21 days of age), 1,000 g per ton of growing diet (22-35 days of age) and $800 \mathrm{~g}$ per ton of finishing diet (36-45 days of age);

- Lactobacillus reuteri and Lactobacillus johnsonir based probiotic was added to drinking water for providing $25 \mathrm{~g}$ of the product for each 5,000 chicks at first day of age.

Birds received diet and water ad libitum throughout the rearing period, which was divided in three phases. In the initial phase (1-21d), birds were fed with starter diet containing 2,944 kcal/kg metabolizable energy, 
Pelicano ERL, Souza PA de, Souza HBA de, Oba A, Norkus EA, Kodawara LM, Lima TMA de
Effect of Different Probiotics on Broiler Carcass and Meat Quality
$23 \%$ crude protein, $1.285 \%$ lysine, $0.537 \%$ methionine, $1.001 \% \mathrm{Ca}$ and $0.481 \%$ total $\mathrm{P}$. In the growing phase $(22-35 \mathrm{~d})$, the diet contained $3,100 \mathrm{kcal} /$ kg metabolizable energy, 20\% crude protein, $1.074 \%$ lysine, $0.388 \%$ methionine, $0.913 \% \mathrm{Ca}$ and $0.377 \%$ total $P$. In The finishing phase (36-45d) diet levels were $3,200 \mathrm{kcal} / \mathrm{kg}$ metabolizable energy, 18\% crude protein, $0.935 \%$ lysine, $0.333 \%$ methionine, $0.803 \%$ $\mathrm{Ca}$ and $0.327 \%$ total $\mathrm{P}$. Other nutritional levels were those recommended by NRC (1994).

Statistical analysis was performed using the software ESTAT 2.0 (1992), and means were compared by Tukey's test.

\section{Evaluated variables}

\section{- Carcass yield}

At 45 days of age, the birds were slaughtered to evaluate carcass yield and cuts yield. The birds were randomly chosen, identified, individually weighed, allotted to pens and fasted for 6 hours with water ad libitum. In the processing plant, they were re-weighed, slaughtered (stunning, bleeding, scalding, plucking, chilling and dripping), and carcasses were weighed without feet, head and neck. Cuts were performed and yields were calculated: legs, breast, back, wings and abdominal fat (\%).

\section{- Color}

The color values of Cielab Colour System (1976), L* (lightness) $a *$ (redness) and $b$ * (yellowness), were determined 45 minutes (at the moment of slaughter) and 5 hours after slaughter using a tristimulus analyser (Minolta Chroma Meter CR-200). At each time, two readings were done in breast muscle and the mean was calculated for each carcass.

\section{- $\mathbf{p H}$}

The $\mathrm{pH}$ was determined using a Jonhis digital pHmeter (model IpHPJ) directly in breast muscle.

The measurements were done immediately after slaughter (45 minutes) and 5 hours after slaughter in chilled carcasses.

\section{- Water holding capacity}

Water holding capacity was evaluated 5 hours after slaughter, using the methodology described by Hamm (1960). The evaluation is based on measuring water loss when a pressure is applied to the muscle. Meat cubes of $0.5 \mathrm{~g}$ were placed between two filter papers and two glass plates, and a 10-kg-weight was placed on the top glass plate for 5 minutes. The difference in breast muscle weight before and after the procedure represents the water loss. The results were expressed as percentage of exsudated water in relation to the initial sample weight.

\section{- Cooking loss}

Cooking loss was determined five hours after slaughter in an oven pre-warmed to $170^{\circ} \mathrm{C}$. Crude breast muscle samples were weighed and put in trays with aluminum grills previously dried in an incubator. The trays were placed inside the oven until sample core temperature reached $75^{\circ} \mathrm{C}$. Samples were cooled at room temperature, re-weighed and cooking loss was calculated as the difference between the initial and the final sample weights.

\section{- Shearing force}

The samples used for cooking loss were also used to evaluate shearing force (SF) according to methodology proposed by Froning \& Uijttenboogaart (1988). Samples measuring $2.0 \times 2.0 \times 1.13 \mathrm{~cm}^{3}$ were taken from the breast muscle, and placed in the Texture Analyzer TA-XT2i in a way that fibers were oriented perpendicularly to the Warner-Bratzler blade. SF was determined using the mean of six to eight samples.

\section{- Sensory analysis}

Sensory analysis was performed 72 hours after slaughter. Breast muscle samples were previously treated with $1 \%(\mathrm{w} / \mathrm{w})$ of salt and then cooked in a pre-warmed oven $\left(170^{\circ} \mathrm{C}\right)$, until internal temperature reached $75^{\circ} \mathrm{C}$. The samples were standardized (size, codification and tasting temperature) and evaluated by the sensory team. An acceptance test with a nine-point hedonic scale was used for the evaluation of flavor (sensation of taste and smell released by the sample during chewing), texture (perception of the strength that is necessary to obtain the shearing of the sample when biting), preference (sum of all sensory perceptions, expressing the evaluation of the quality of the product by the sensory team) and general aspect (visualization of the product).

\section{RESULTS AND DISCUSSION}

The results of carcass and cut yields are shown in Table 1. Control birds showed higher carcass yield $(p<0.05)$ when compared to the treatments that were given probiotics, and the same was seen for backside yield at 45 days. Other authors found no differences in carcass yield between birds that were fed probiotics and control birds (Moreira et al., 2001; Vargas Jr. et al., 2002). 
Pelicano ERL, Souza PA de, Souza HBA de, Oba A, Norkus EA, Kodawara LM, Lima TMA de

Table 1 - Carcass and cut yields of broilers fed probiotics in the diet and drinking water (45 days-old).

\begin{tabular}{|c|c|c|c|c|c|c|}
\hline \multirow[t]{2}{*}{ Variables } & \multicolumn{6}{|c|}{ Yield (\%) } \\
\hline & Carcass & Legs & Breast & Back & Wings & Fat \\
\hline \multicolumn{7}{|c|}{ Probiotic in diet (D) } \\
\hline Probic & $72.49 a$ & $34.23 a$ & $29.36 a$ & $23.42 a$ & $11.23 a$ & $1.76 a$ \\
\hline & & & & & 1 & \\
\hline & & & & & 11.4 & \\
\hline & & & & & $0.33 \mathrm{~ns}$ & 0.5 \\
\hline & 2.91 & 1.29 & 1.43 & 1.78 & 0.57 & \\
\hline \multicolumn{7}{|c|}{ Probiotic in drinking water (W) } \\
\hline No & & a & $a$ & a & $11.27 a$ & $68 \mathrm{a}$ \\
\hline With & $c^{(4)} 71$ & $33.80 \mathrm{a}$ & 29.1 & $24.02 a$ & $11.39 a$ & $1.66 a$ \\
\hline Test & $0.08 \mathrm{~ns}$ & $1.33 \mathrm{~ns}$ & $0.02 \mathrm{~ns}$ & $0.30 \mathrm{~ns}$ & $0.48 \mathrm{~ns}$ & $0.05 \mathrm{~ns}$ \\
\hline & 1.97 & 0.87 & 0.97 & 1.21 & 0.38 & 0.24 \\
\hline \multicolumn{7}{|c|}{ Control vs Factorial } \\
\hline Con & $55 \mathrm{a}$ & b & a & $1 \mathrm{a}$ & $11.01 \mathrm{a}$ & $1.73 \mathrm{a}$ \\
\hline & & & & 23. & $11.33 a$ & $1.68 \mathrm{a}$ \\
\hline Tes & 4 & ** & & 3 * & $1.66 \mathrm{nsC}$ & 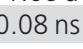 \\
\hline & & ns & & $0.43 \mathrm{~ns}$ & & $1.04 \mathrm{~ns}$ \\
\hline $\mathrm{CV}(\%)$ & 3.64 & 3.45 & 4.44 & 6.69 & 4.53 & 18.62 \\
\hline \multicolumn{7}{|c|}{$\begin{array}{l}a, b-\text { For each independent factor, means followed by different letters } \\
\text { within column are different }(p<0.05) \text { by Tukey's test. LSD - Least significant } \\
\text { difference. (1) Probiotic added to diet - Bacillus subtilis }\left(10^{10} \mathrm{CFU} / \mathrm{g} \text { product). }\right. \\
\text { (2) Probiotic added to diet - Bacillus subtilis }\left(1.6 \times 10^{9} \mathrm{CFU} / \mathrm{g} \text { product) and }\right. \\
\text { Bacillus licheniformis }\left(1.6 \times 10^{9} \mathrm{CFU} / \mathrm{g}\right) \text {. (3) Probiotic added to diet - } \\
\text { Saccharomyces cerevisiae }\left(8 \times 10^{9} \mathrm{CFU} / \mathrm{g} \text { product). (4) Probiotic added to }\right. \\
\text { drinking water - Lactobacillus reuteri }\left(6.6 \times 10^{9} \mathrm{CFU} / \mathrm{g}\right) \text { and Lactobacillus } \\
\text { johnsonii }\left(3.3 \times 10^{9} \mathrm{CFU} / \mathrm{g}\right) \text {. }\end{array}$} \\
\hline
\end{tabular}

Concerning cut yields, treatments receiving any kind of probiotic showed higher leg yield $(p<0.01)$, similar to what had been reported previously by Corrêa et al. (2000) and Santos et al. (2002). On the other hand, Henrique et al. (1998) and Loddi et al. (2000) observed no differences in leg yield between control birds and those receiving additives. Although a higher carcass yield has been observed in the control birds, cut yields showed that the prime cuts (wings and breast) were not different among groups or they differed positively when probiotics were added (legs). It was also observed that probiotic decreased abdominal fat, although not statistically different. This result may be attributed to the reducing effect of probiotics on fat deposition (Mohan et al., 1996; Jin et al., 1998).

Tables 2 and 3 show that the concomitant use of probiotics in drinking water and diet reduced significantly the values of $L$ * (lightness) in breast muscle 45 minutes and 5 hours after slaughter, resulting in a less pale meat. According to Contreras \& Beraquet (1995), values of $L^{*}$ from 46.4 to 49.7 for the breast color are normal. In the present study, the association between products caused, 5 hours after slaughter, luminosity mean level (48.10) within this normal range. Values of $a^{*}$ (redness) were higher $(p<0.05)$ in probiotics-treated groups (4.52) than in control group (3.79) 45 minutes after slaughter, but not later. The color of broiler meat in natura is important because consumers associate it to fresh and high-quality products (Contreras, 2001). Since the use of probiotics had no interference on meat color when compared to the control group at the last measurement (5 hours after slaughter), these products may be used because they do not interfere on color, a parameter that is so important to consumers and that is directly related to product acquisition.

Table 2 - Color of breast muscle at slaughter in broilers fed probiotics in the diet and drinking water.

\begin{tabular}{|c|c|c|c|}
\hline Variables & $\begin{array}{l}\text { L* value } \\
\text { (lightness) }\end{array}$ & $\begin{array}{r}a * \text { value } \\
\text { (redness) }\end{array}$ & $\begin{array}{c}\text { b* value } \\
\text { (yellowness) }\end{array}$ \\
\hline \multicolumn{4}{|c|}{ Probiotic in Diet (D) } \\
\hline Probiotic $1^{(1)}$ & $45.65 a$ & $4.27 \mathrm{a}$ & $4.39 a$ \\
\hline Probiotic $2^{(2)}$ & $45.44 a$ & $4.79 a$ & $4.37 \mathrm{a}$ \\
\hline Probiotic $3^{(3)}$ & $45.37 a$ & $4.49 a$ & $4.24 \mathrm{a}$ \\
\hline Test F & $0.11 \mathrm{~ns}$ & $1.93 \mathrm{~ns}$ & $0.05 \mathrm{~ns}$ \\
\hline LSD (5\%) & 1.50 & 0.66 & 1.24 \\
\hline \multicolumn{4}{|c|}{ Probiotic in drinking water (W) } \\
\hline No Probiotic & $46.03 a$ & $4.54 \mathrm{a}$ & $4.21 \mathrm{a}$ \\
\hline With Probiotic (4) & $44.94 \mathrm{~b}$ & $4.50 a$ & $4.46 a$ \\
\hline Test $F$ & 4.88 * & $0.02 \mathrm{~ns}$ & $0.38 \mathrm{~ns}$ \\
\hline LSD (5\%) & 1.02 & 0.45 & 0.84 \\
\hline \multicolumn{4}{|c|}{ Control vs Factorial } \\
\hline Control & $45.11 \mathrm{a}$ & $3.79 b$ & $5.25 a$ \\
\hline Factorial & $45.48 \mathrm{a}$ & $4.52 \mathrm{a}$ & $4.33 a$ \\
\hline Test F & $0.33 \mathrm{~ns}$ & 6.36 * & $2.90 \mathrm{~ns}$ \\
\hline$D \times W$ & $1.07 \mathrm{~ns}$ & $1.20 \mathrm{~ns}$ & $0.17 \mathrm{~ns}$ \\
\hline CV $(\%)$ & 2.99 & 13.51 & 25.14 \\
\hline
\end{tabular}

a,b - For each independent factor, means followed by different letters within column are different $(p<0.05)$ by Tukey's test. LSD - Least significant difference. (1) Probiotic added to diet - Bacillus subtilis $\left(10^{10} \mathrm{CFU} / \mathrm{g}\right.$ product). (2) Probiotic added to diet - Bacillus subtilis $\left(1.6 \times 10^{9} \mathrm{CFU} / \mathrm{g}\right.$ product) and Bacillus licheniformis (1.6 $\left.\times 10^{9} \mathrm{CFU} / \mathrm{g}\right)$. (3) Probiotic added to diet Saccharomyces cerevisiae $\left(8 \times 10^{9} \mathrm{CFU} / \mathrm{g}\right.$ product). (4) Probiotic added to drinking water - Lactobacillus reuteri $\left(6.6 \times 10^{9} \mathrm{CFU} / \mathrm{g}\right)$ and Lactobacillus johnsonii( $\left(3.3 \times 10^{9} \mathrm{CFU} / \mathrm{g}\right)$

The probiotics association, 5 hours after slaughter, showed a $\mathrm{pH}$ decrease (Table 4) that was significantly less prominent $(5.87 \times 5.75)$ when it was compared to the probiotics given only in diet $(5.84 \times 5.66)$. Muscle transforms into meat due to some biochemical processes (Forrest et al., 1975), among them, alterations in $\mathrm{pH}$, which is close to 7.4 in vivo. According to Sanudo (1992), meat quality is influenced by the alterations that 
occur on the $\mathrm{pH}$ during the rigor mortis. Meat color alterations, which occur in swine, such as PSE (pale, soft and exsudative) and DFD meat (dark, firm and dry), are rare in birds. Nevertheless, changes in color that are similar to PSE have already been described in broilers (Northcutt, 1994; Uijttenboogart \& Reimert, 1994). One of the most important methods to identify such alterations in meat are objective colorimetric measurements from the CIELAB system, which determines the parameters $L^{*}, a^{*}$ and $b^{*}$ (Barbut, 1993). According to Jones \& Grey (1989) and Sams \& Mills (1993), normal pH values at the end of the postmorten process are between 5.60 to 5.80 and 5.78 to 5.86 , respectively. The data presented here are within these values independently of probiotics utilization.

Table 3 -Color of breast muscle 5 hours after slaughter in broilers fed probiotics in the diet and drinking water

\begin{tabular}{|c|c|c|c|}
\hline Variables & $\begin{array}{l}\text { L* value } \\
\text { (lightness) }\end{array}$ & $\begin{array}{r}\text { a* value } \\
\text { (redness) }\end{array}$ & $\begin{array}{c}\mathbf{b}^{*} \text { value } \\
\text { (yellowness) }\end{array}$ \\
\hline \multicolumn{4}{|c|}{ Probiotic in diet (D) } \\
\hline Probiotic $1^{(1)}$ & $49.02 \mathrm{a}$ & $4.41 \mathrm{a}$ & $4.10 \mathrm{a}$ \\
\hline Probiotic $2^{(2)}$ & $49.13 a$ & $4.80 \mathrm{a}$ & $3.80 \mathrm{a}$ \\
\hline Probiotic $3^{(3)}$ & 48.93 a & $4.71 \mathrm{a}$ & $3.91 \mathrm{a}$ \\
\hline Test F & $0.02 \mathrm{~ns}$ & $1.04 \mathrm{~ns}$ & $0.17 \mathrm{~ns}$ \\
\hline $\operatorname{LSD}(5 \%)$ & 2.33 & 0.71 & 1.31 \\
\hline \multicolumn{4}{|c|}{ Probiotic in drinking water (W) } \\
\hline No Probiotic & $49.95 \mathrm{a}$ & $4.60 \mathrm{a}$ & $3.88 \mathrm{a}$ \\
\hline With Probiotic (4) & $48.10 \mathrm{~b}$ & $4.68 \mathrm{a}$ & $3.99 \mathrm{a}$ \\
\hline Test F & 5.80 * & $0.12 \mathrm{~ns}$ & $0.07 \mathrm{~ns}$ \\
\hline $\operatorname{LSD}(5 \%)$ & 1.57 & 0.48 & 0.88 \\
\hline \multicolumn{4}{|c|}{ Control vs Factorial } \\
\hline Control & $48.81 \mathrm{a}$ & $4.24 \mathrm{a}$ & $4.98 \mathrm{a}$ \\
\hline Factorial & 49.03 a & $4.64 \mathrm{a}$ & $3.93 \mathrm{a}$ \\
\hline Test F & $0.04 \mathrm{~ns}$ & $1.63 \mathrm{~ns}$ & $3.38 \mathrm{~ns}$ \\
\hline$D \times W$ & $0.81 \mathrm{~ns}$ & $2.53 \mathrm{~ns}$ & $0.03 \mathrm{~ns}$ \\
\hline $\mathrm{CV}(\%)$ & 4.29 & 14.02 & 28.91 \\
\hline \multicolumn{4}{|c|}{$\begin{array}{l}\text { a,b - For each independent factor, means followed by different letters } \\
\text { within column are different (P<0.05) by Tukey's test. LSD - Least significant } \\
\text { difference. (1) Probiotic added to diet - Bacillus subtilis }\left(10^{10} \mathrm{CFU} / \mathrm{g} \text { product). }\right. \\
\text { (2) Probiotic added to diet - Bacillus subtilis }\left(1.6 \times 10^{9} \mathrm{CFU} / \mathrm{g} \text { product) and }\right. \\
\text { Bacillus licheniformis }\left(1.6 \times 10^{9} \mathrm{CFU} / \mathrm{g}\right) \text {. (3) Probiotic added to diet - } \\
\text { Saccharomyces cerevisiae }\left(8 \times 10^{9} \mathrm{CFU} / \mathrm{g} \text { product). (4) Probiotic added to }\right. \\
\text { drinking water - Lactobacillus reuteri }\left(6.6 \times 10^{9} \mathrm{CFU} / \mathrm{g}\right) \text { and Lactobacillus } \\
\text { johnsonii }\left(3.3 \times 10^{9} \mathrm{CFU} / \mathrm{g}\right) \text {. }\end{array}$} \\
\hline
\end{tabular}

No differences were observed in $\mathrm{pH}$ values at 45 minutes and 5 hours after slaughter between control birds and the birds fed probiotics, corroborating the findings from Quadros et al. (2001).

Water holding capacity (WHC) and cooking loss (CL) 5 hours after slaughter were not different among different probiotics or between them and the control group (Table 5). It is interesting to note that water loss reduces the meat nutritional value because some nutrients may be lost in the exsudate, resulting in a meat less tender and worst in flavor, which was not the case observed in this study.

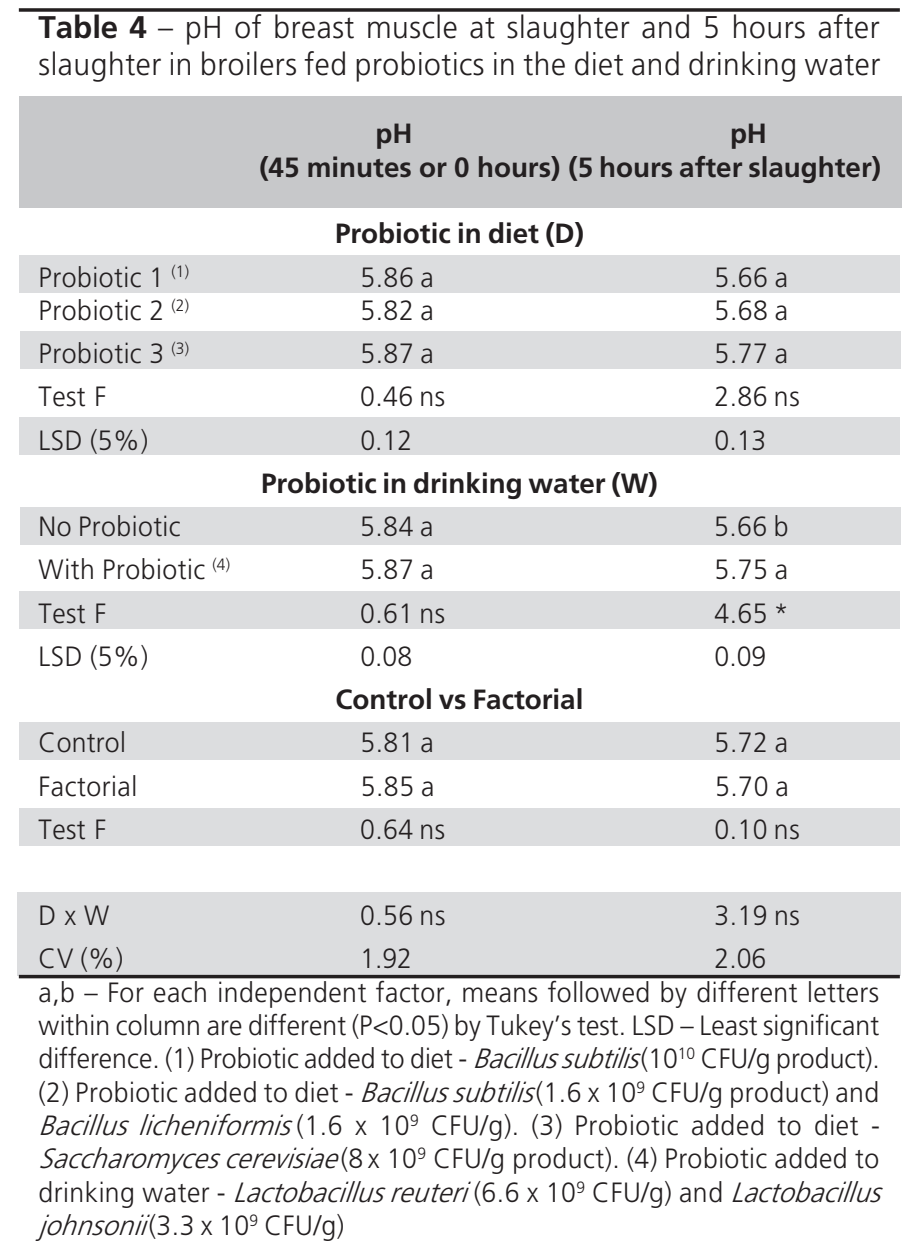

Table 5 also shows that no statistical difference was found among the treatments for shearing force (SF), corroborating previous findings of breast meat in swine (Quadros et al., 2001). According to Contreras (1995), SF values in conventional boned breast muscle were between 5.5 to $5.8 \mathrm{kgf} / \mathrm{g}$. Lyon \& Lyon (1990) considered that values up to $7.5 \mathrm{kgf} / \mathrm{g}$ might be considered as tender, while Simpson \& Goodwin (1974) proposed values up to $8 \mathrm{kgf} / \mathrm{g}$. Considering these reference values, probiotics did not affect meat tenderness in the present study, since SF values were between 3.1 to $3.8 \mathrm{kgf} / \mathrm{g}$.

WHC, CL and SF are quality parameters closely correlated to the process of meat tenderness, which is a determinant qualitative factor and one of the most important sensory characteristics of meat (Koohmaraie 
Table 5 -Water holding capacity (WHC), cooking loss (CL) and shearing force (SF) 5 hours after slaughter in breast meat of broilers fed probiotics in the diet and drinking water.

\begin{tabular}{|c|c|c|c|}
\hline & WHC (\%) & $\mathrm{CL}(\%)$ & $S F(k g f / g)$ \\
\hline & \multicolumn{3}{|c|}{ Probiotic in diet (D) } \\
\hline Probiotic $1^{(1)}$ & $72.33 a$ & $28.82 \mathrm{a}$ & $3.8 \mathrm{a}$ \\
\hline Probiotic $2^{\text {(2) }}$ & $72.96 a$ & $29.72 a$ & $3.5 \mathrm{a}$ \\
\hline Probiotic $3^{(3)}$ & $74.09 \mathrm{a}$ & $29.90 \mathrm{a}$ & $3.1 \mathrm{a}$ \\
\hline Test $\mathrm{F}$ & $1.15 \mathrm{~ns}$ & $0.31 \mathrm{~ns}$ & $2.16 \mathrm{~ns}$ \\
\hline LSD (5\%) & 2.89 & 3.66 & 786.80 \\
\hline \multicolumn{4}{|c|}{ Probiotic in drinking water (W) } \\
\hline No Probiotic & $72.90 \mathrm{a}$ & $29.22 a$ & $3.5 \mathrm{a}$ \\
\hline With Probiotic (4) & $73.35 a$ & $29.73 a$ & $3.5 a$ \\
\hline Test $\mathrm{F}$ & $0.22 \mathrm{~ns}$ & $0.18 \mathrm{~ns}$ & $0.00 \mathrm{~ns}$ \\
\hline LSD (5\%) & 1.96 & 2.47 & 531.81 \\
\hline \multicolumn{4}{|c|}{ Control vs Factorial } \\
\hline Control & $73.15 \mathrm{a}$ & $32.14 \mathrm{a}$ & $3.2 \mathrm{a}$ \\
\hline Factorial & $73.13 a$ & $29.48 a$ & $3.5 \mathrm{a}$ \\
\hline Test F & $0.00 \mathrm{~ns}$ & $2.79 \mathrm{~ns}$ & $0.53 \mathrm{~ns}$ \\
\hline$D \times W$ & $1.23 \mathrm{~ns}$ & $0.28 \mathrm{~ns}$ & $0.27 \mathrm{~ns}$ \\
\hline $\mathrm{CV}(\%)$ & 3.57 & 11.07 & 20.63 \\
\hline
\end{tabular}

a - For each independent factor, means followed by same letters within column are not different ( $p>0.05$ ) by Tukey's test. LSD - Least significant difference. (1) Probiotic added to diet - Bacillus subtilis (1010 $\mathrm{CFU} / \mathrm{g}$ product). (2) Probiotic added to diet - Bacillus subtilis $\left(1.6 \times 10^{9} \mathrm{CFU} / \mathrm{g}\right.$ product) and Bacillus licheniformis $\left(1.6 \times 10^{9} \mathrm{CFU} / \mathrm{g}\right)$. (3) Probiotic added to diet Saccharomyces cerevisiae $\left(8 \times 10^{9} \mathrm{CFU} / \mathrm{g}\right.$ product). (4) Probiotic added to drinking water - Lactobacillus reuteri $\left(6.6 \times 10^{9} \mathrm{CFU} / \mathrm{g}\right)$ and Lactobacillus johnsonii( $\left.3.3 \times 10^{9} \mathrm{CFU} / \mathrm{g}\right)$.

Results of sensory analysis are shown in Table 6. Significant differences were observed in meat flavor $(p<0.01)$ and general aspect $(p<0.05)$ when an association of probiotics was used instead of using the probiotic only in diet, which resulted in a better tasting grade 72 hours after slaughter. According to Liu \& Stouffer (1995), the three major sensory properties that interfere with meat quality evaluation are general aspect, texture and flavor; whereas Gray et al. (1996) considered that general aspect is the most important, since it influences the consumer's decision on buying or not the product.

Texture did not differ among probiotics or between them and the control group. Nevertheless, a negative correlation tendency was observed between SF and texture (Table 5); higher texture grades in the sensory analysis were correlated with smaller SF to break the breast samples. According to Felício (2002), there is a high to moderate correlation between tenderness physical measurement and sensory evaluation, which means that a meat considered tender by SF evaluation, much probably, should be considered tender by trained panelists.
Table 6 - Flavor, texture, preference and general aspect described in sensory analysis 72 hours after slaughter in breast meat of broilers fed probiotics in the diet and drinking water.

\begin{tabular}{|c|c|c|c|c|}
\hline Flavor & Texture & Preference & General & Aspect \\
\hline \multicolumn{5}{|c|}{ Probiotic in diet (D) } \\
\hline Probiotic $1^{(1)}$ & $6.59 a$ & $6.61 \mathrm{a}$ & $6.48 a$ & $6.57 \mathrm{a}$ \\
\hline Probiotic $2^{(2)}$ & $6.66 \mathrm{a}$ & $6.91 \mathrm{a}$ & $6.61 \mathrm{a}$ & $6.45 a$ \\
\hline Probiotic $3^{(3)}$ & $6.66 a$ & $7.00 \mathrm{a}$ & $6.80 a$ & $6.73 a$ \\
\hline Test F & $0.04 \mathrm{~ns}$ & $0.41 \mathrm{~ns}$ & $0.54 \mathrm{~ns}$ & $0.43 \mathrm{~ns}$ \\
\hline $\operatorname{LSD}(5 \%)$ & 0.70 & 0.70 & 0.73 & 0.70 \\
\hline \multicolumn{5}{|c|}{ Probiotic in drinking water (W) } \\
\hline No Probiotic & $6.32 b$ & $6.92 \mathrm{a}$ & $6.39 a$ & $6.32 b$ \\
\hline With Probiotic ${ }^{(4)}$ & $6.95 a$ & $6.76 a$ & $6.86 a$ & $6.85 a$ \\
\hline Test F & 7.03 ** & $0.47 \mathrm{~ns}$ & $3.51 \mathrm{~ns}$ & 4.82 * \\
\hline LSD (5\%) & 0.47 & 0.48 & 0.50 & 0.48 \\
\hline \multicolumn{5}{|c|}{ Control vs Factorial } \\
\hline Control & $6.86 a$ & $7.05 a$ & $6.77 a$ & $6.77 \mathrm{a}$ \\
\hline Factorial & $6.64 a$ & $6.84 a$ & $6.63 a$ & $6.58 a$ \\
\hline Test F & $0.51 \mathrm{~ns}$ & $0.41 \mathrm{~ns}$ & $0.19 \mathrm{~ns}$ & $0.35 \mathrm{~ns}$ \\
\hline$D \times W$ & $1.59 \mathrm{~ns}$ & $0.52 \mathrm{~ns}$ & $0.54 \mathrm{~ns}$ & $2.60 \mathrm{~ns}$ \\
\hline $\mathrm{CV}(\%)$ & 20.68 & 20.31 & 21.66 & 20.99 \\
\hline
\end{tabular}

$\mathrm{a}, \mathrm{b}$ - For each independent factor, means followed by different letters within column are different $(p<0.05)$ by Tukey's test. LSD - Least significant difference. (1) Probiotic added to diet - Bacillus subtilis $\left(10^{10} \mathrm{CFU} / \mathrm{g}\right.$ product) (2) Probiotic added to diet - Bacillus subtilis (1.6 $\times 10^{9} \mathrm{CFU} / \mathrm{g}$ product) and Bacillus licheniformis (1.6 × $\left.10^{9} \mathrm{CFU} / \mathrm{g}\right)$. (3) Probiotic added to diet Saccharomyces cerevisiae ( $8 \times 10^{9} \mathrm{CFU} / \mathrm{g}$ product). (4) Probiotic added to drinking water - Lactobacillus reuteri $\left(6.6 \times 10^{9} \mathrm{CFU} / \mathrm{g}\right)$ and Lactobacillus johnsoniil(3.3 $\left.\times 10^{9} \mathrm{CFU} / \mathrm{g}\right)$

The control group also did not differed from the groups receiving probiotic (water/diet), corroborating the findings of Loddi et al. (2000) and disagreeing to those from Jensen \& Jensen (1992), who reported a positive effect of Bacillus licheniformis and Bacillus subtilis spores on the flavor of broiler meat after cooling for 5 days.

\section{CONCLUSION}

The findings of this study evidenced that the presence or absence of probiotics had no effect on carcass yield. Nevertheless, leg yield was higher in the birds that received probiotics. The concomitant use of probiotics in water and feed increased meat quality in relation to color, $\mathrm{pH}$, tenderness and general aspect.

\section{REFERENCES}

Barbut S. Color measurements for evaluating the pale soft exsudative (PSE) occurrence in turkey meat. Food Research International 1993; 26(1):39-43. 
Burkett RF, Thayer RH, Morrison RD. Supplementing market broiler diets with Lactobacillus and live yeast cultures. Animal Science Agricultural Research Report. Oklahoma State University and USDA. USA. 1977

Contreras CJC. Efeitos do atordoamento elétrico, estimulação elétrica e da desossa à quente na qualidade da carne do peito de frango "Pectoralis major". [Tese]. Campinas (SP):Faculdade de Engenharia de Alimentos, Universidade Estadual de Campinas, 1995; 150p.

Contreras CJC, Beraquet NJ. Effect of deboning and electrical stimulation on post mortem biochemical changes in chicken breast P. major. In:International Congress of Meat Science and Technology, 41 th The Hague, Netherlands. Proceedings...The Hague, 1995; 4(S-IVB):46. 41

Contreras CJC. Qualidade de carcaça e carne de aves. In:I Congresso Brasileiro de Ciência e Tecnologia de Carnes, 2001, São Pedro. Anais. São Pedro, 2001; p.160-178.

Corrêa GSS, Gomes AVC, Corrêa AB, Salles AS. Desempenho de frangos de corte alimentados com diferentes promotores de crescimento. In:Reunião Anual da SBZ, 2000, Viçosa. Anais. Viçosa, 2000; p. 37.

Dale N. Probióticos para aves. Avicultura Profesional 1992; 10(2):88-89.

ESTAT 2.0 Sistema de Análise Estatística. Jaboticabal:Polo Computacional - Departamento de Ciências Exatas - UNESP; 1992.

Felício PE. Qualidade da carne bovina:características físicas e organolépticas. www.sbz.org.br/eventos/PortoAlegre/homepages bz/Pedro_Felicio.htm. 2002.

Forrest JC, Aberle ED, Hedrich HB, Judge MD, Merkel RA. Principles of meat science. Freeman, San Francisco, California, 1975; 417 p.

Froning GW, Uijttenboogaart TG. Effect of post mortem electrical stimulation on color, texture, $\mathrm{pH}$, and cooking loss of hot and cold deboned chicken breast meat. Poultry Science 1988; 67(11):1536-1544.

Fuller R. Probiotics in man and animals. A review. Journal of Applied Bacteriology 1989; 66:365-378.

Gray JI, Gomaa EA, Buckley DJ. Oxidative quality and Shelf life of meats. Meat Science 1996; 43:111-123.

Hamm R. Biochemistry of meat hydratation. Advances in Food Research 1960; 10(2):335-443

Henrique APF, Faria DE, Franzolin R, Ito DT. Efeito de ácido orgânico, probiótico e antibiótico sobre o desempenho e rendimento de carcaça de frangos de corte. In:XXXV Reunião Anual da SBZ, 1998, Botucatu. Anais. Botucatu:SBZ, 1998; p. 300-302.

Jensen JF, Jensen MM. The effect of using growth promoting Bacillus strains in poultry feed. In:World's Poultry Congress, 18,
1992, Amsterdam. Proc. Amsterdam:WPSA, 1992; 3:398-402. Jones JM, Grey TC. Influence of processing on product quality and yield. In:Processing of Poultry. G.C. Mead (ed.), 1989; p. 127-130

Koohmaraie M, Whipple G, Crousse L. Acceleration of post mortem tenderization in lamb and Brahman-cross beef carcasses through infusion of calcium chloride. Journal of Animal Science 1990; 68(5):1278-1283.

Liu Y, Stouffer JR. Pork carcass evaluation with an automated and computerized ultrasonic system. Journal of Animal Science 1995; 73:29-38.

Loddi MM, Gonzales E, Takita TS, Mendes AAM, Roça RO. Uso de probiótico e antibiótico sobre o desempenho, rendimento e qualidade de carcaça de frangos de corte. Revista Brasileira de Zootecnia 2000; 29(4):1124-1131.

Lyon CE, Lyon BG. The relationship of objective shear value and sensory tests to changes in tenderness of broiler breast meat. Poultry Science 1990; 69(8):1420-1427.

Maruta K. Probióticos e seus benefícios. In.Conferência APINCO de Ciência e Tecnologia Avícolas; 1993; Santos, São Paulo. Brasil. p. 203-219.

Menten JFM. Aditivos alternativos na nutrição de aves:Probióticos e Prebióticos. Sociedade Brasileira de Zootecnia - A produção animal na visão dos brasileiros, Piracicaba:Fealq, 2001; p. 141157.

Menten JFM. Probióticos, Prebióticos e Aditivos Fitogênicos na Nutrição de Aves. In:II Simpósio sobre Ingredientes na Alimentação Animal CBNA, 2002; p. 251-275.

Moreira J, Mendes AA, Garcia EA, Garcia RG, Almeida ICL, JR. $J G C$. Efeito do uso do probiótico sobre o desempenho e rendimento de carcaça em frangos de corte. In:XXXVIII Reunião Anual da SBZ, 2001, Piracicaba. Anais. Piracicaba, 2001; p. 852854.

Mohan B, Kadirvel R, Natarajan A, Bhaskaran M. Effect of probiotic supplementation on growth, nitrogen utilization and serum cholesterol in broilers. British Poultry Science 1996; 37:395-401.

Northcutt JK. Influence of antemortem treatment on post mortem muscle properties of poultry meat. Dissertation Abstracts International. Abstract of thesis, B, 55 (2) 245-246 Order no. DA9417648, 175 p. North Carolina State Univ. USA. 1994

NRC - National Research Council. Nutrient Requirements of Poultry. $9^{\text {th }}$ revised ed. Washington:National Academy Of Science Press, 1994. 156p.

Owings WJ, Reynoldas DL, Hasiak RJ, Ferket PR. Influence of dietary supplementation with Streptococcus faecium M - 74 on broiler body weight, feed conversion, carcass characteristics, and intestinal microbial colonization. Poultry Science 1990; 69:12571264. 
Quadros ARB, Kiefer C, Ribeiro NLC, Zink LA. Características qualitativas da carne de suínos alimentados com rações contendo ou não probióticos. In:XXXVIII Reunião Anual da SBZ, 2001, Piracicaba. Anais. Piracicaba, 2001; p. 794-795.

Sams AR, Mills KA. The effect of feed withdrawal duration on the responsiveness of broiler pectoralis to rigor mortis acceleration. Poultry Science 1993; 72(9):1789-1796.

Santos EC, Teixeira AS, Rodrigues PB, Bertechini AG, Freitas RTF, Dias ES, Torres DM, Santos AV, Giacometi R. Uso de aditivos beneficiadores de crescimento sobre o rendimento de carcaça de frangos de corte. In:XXXIX Reunião Anual da SBZ, 2002, Recife. Anais...Recife, 2002, CD ROM.

Sanudo C. La calidad organoléptica de la carne (II). Mundo Ganadero 1992; 10:78-86.

Simpson MD, Goodwin TL. Comparison between shear values and test panel scores for predicting tenderness of broilers. Poultry Science 1974; 53 (6):2042-2046.

Tabelas da Avicultura. Aves \& Ovos, 11, 1995.

Uijttenboogaart TG, Reimert HGM. Effects of the method of chilling, electrical stimulation and boning time on quality characteristics of chicken breast meat. In:International Conference of Meat Science Technology. 40 th the Hague, Netherlands. Proceedings...The Hague, 1994; v. 4, n. S-IVB. 41.

Vargas Jr JG, Toledo RS, Albino LFT, Rostango HS, Oliveira JE, Carvalho DCO. Características de carcaça de frango de corte, submetidos a rações contendo probióticos, prebióticos e antibióticos. In:XXXIX Reunião Anual da SBZ, 2002, Recife. Anais...Recife, 2002, CD ROM. 